\title{
MENINGKATKAN KESEHATAN MENTAL DI MASA PANDEMIC
}

\author{
Yuli Asmi Rozali, Novendawati Wahyu Sitasari, Amanda Lenggogeni \\ Fakultas Psikologi Universitas Esa Unggul, Jakarta \\ Jalan Arjuna Utara Tol Tomang Kebon Jeruk, Jakarta 11510 \\ yuli.azmi@esaunggul.ac.id
}

\begin{abstract}
The Covid-19 pandemic has forced many people, almost all age groups in various countries, to undergo new habits have the potential to undermine mental health. Starting from health workers, students who cannot go to school, workers who are at risk of being exposed to Covid-19 and are threatened with a wave of layoffs, people who are falling into poverty because the economy continues to deteriorate, to those who have to undergo isolation during lock down, all face a reduction risk mental health qualities. The purpose of this Community Service Program is to increase public understanding of the importance of maintaining mental health both during the pandemic and in the next life. P2M is given to all levels of society. With the intervention method in the form of seminars, the effectiveness of this program was measured using a survey method and a questionnaire on mental health. The results of the Community Service Program activities carried out, it can be concluded that the provision of information and knowledge about mental health can affect the ability of participants to deal with mental health disorders. There were also more participants who understood the material presented (64\%) than participants who did not understand, and $66 \%$ of peseta thought that the program had been achieved.
\end{abstract}

Keyword : Pandemic, mental health

\begin{abstract}
Abstrak
Pandemi Covid-19 telah membuat banyak orang, hampir dari semua kelompok umur di berbagai negara, terpaksa menjalani kebiasaan baru yang berpotensi meruntuhkan kesehatan mental. Mulai dari para petugas kesehatan, siswa-siswi yang tidak bisa ke sekolah, pekerja yang berisiko terpapar Covid19 dan terancam gelombang PHK, masyarakat yang jatuh miskin karena ekonomi terus memburuk, hingga mereka yang harus menjalani isolasi saat lock down, semua menghadapi risiko penurunan kualitas kesehatan mental. Tujuan dari Program Pengabdian Masyarakat ini adalah untuk meningkatkan pemahaman masyarakat mengenai penting nya menjaga kesehatan mental baik di masa pandemic maupun kehidupan selanjutnya. P2M ini diberikan pada seluruh lapisan masyarakat. Dengan metode intervensi berupa pemberian seminar, efektivitas dari program ini diukur dengan menggunakan metode survey dan kuesioner mengenai kesehatan mental. Hasil dari Kegiatan Program Pengabdian Masyarakat yang dilakukan, dapat disimpulkan bahwa pemberian informasi dan pengetahuan mengenai kesehatan mental dapat mempengaruhi kemampuan peserta dalam menghadapi gangguan kesehatan mental. Peserta yang memahami materi yang disampaikan juga lebih banyak (64\%) dibandingkan peserta yang kurang memahami, dan 66\% peseta menilai bahwa program yang dilakukan tercapai.
\end{abstract}

Kata kunci : pandemic, kesehatan mental

\section{Pendahuluan}

Ahli kesehatan Perserikatan Bangsa-bangsa mengisyaratkan adanya krisis kesehatan jiwa akibat pandemi (Anwar, 2020). Pandemi bukan hanya berdampak secara sosial dan finansila tetapi juga secara mental. Saat memperingati Hari Kesehatan Mental Sedunia yang lalu, WHO menilai bahwa peringatan Hari Kesehatan Mental Sedunia tahun ini memiliki makna khusus. Sebab, pandemi Covid-19 telah membuat banyak orang, hampir dari semua kelompok umur di berbagai negara, terpaksa menjalani kebiasaan baru yang berpotensi meruntuhkan kesehatan mental.Mulai dari para petugas kesehatan, siswa-siswi yang tidak bisa ke sekolah, pekerja yang berisiko terpapar Covid-19 dan terancam gelombang PHK, masyarakat yang jatuh miskin karena ekonomi terus memburuk, hingga mereka yang harus menjalani isolasi saat lock down, semua menghadapi risiko penurunan kualitas kesehatan mental. Ditambah para keluarga korban Covid yang kehilangan anggota keluarga yang dicintai karena tidak bisa mengucapkan dan melihat untuk yang terakhir kalinya. (WHO, 2020). Bombardir berita mengenai Covid-19 menjadi sumber stress tersendiri menjadi pemicu tidak berfungsinya kesehatan mental dengan baik.

Seperti yang dipaparkan oleh Anwar (2020), di Indonesia, Kepala Staf Presiden, Moeldoko menyatakan bahwa selama periode 16 - 30 Maret 2020 saja ada 59 kasus kekerasan, perkosaan, dan pelecehan. Sementara itu Kepala Bagian Penerangan Umum (Kabagpenum) Polri, Kombes Asep Adi 
Saputra mengatakan peningkatan angka kejahatan selama masa pandemi Corona sekitar 11,8 persen (CNN Indonesia, 2020). Kriminolog, Reza Indragiri, seperti dikutip oleh CNN Indonesia (2020) menyatakan kesulitan ekonomi dan rasa frustasi selama pembatasan sosial berskala besar (PSBB) dapat memicu seseorang untuk melakukan tindak kekerasan dan kejahatan. Informasi dan data yang ditemukan menunjukkan bahwa saat ini Negara Indonesia sedang mengalami peningkatan masalah kesehatan mental terutama sejak masa pandemic berlangsung.Menurut hasil suvey yang dilakukan oleh Perhimpunan Dokter Spesialis Kedokteran Jiwa Indonesia, dari 2.364 responden yang berasal dari 34 provinsi diketahui bahwa terdapat $31 \%$ tidak ada masalah psikologis dan 69\% mengalami masalah psikologis. Dan diketahui juga bahwa terdapat $68 \%$ responden yang mengalami cemas, $67 \%$ depresi dan $77 \%$ trauma psikologis. Responden yang mengalami depresi berpikir kematian $49 \%$.

Gejala mulai timbulnya kecemasan satu hari setelah Pemerintah mengumumkan bahwa ada kasus corona di Indonesia. etelah itu muncul berbagai reaksi di masyarakat dan terlihat kecemasan cepat sekali menghinggapi setiap orang yg menyebabkannya melakukan perilaku: memborong masker, sanitizer, sembako, banyak orang menggunakan masker di tempat-tempat umum, dll. Rasa cemas adalah reaksi emosi yg wajar yang disebabkan oleh suatu keadaan yg tidak diharapkan yang diasumsikan dapat menimbulkan bahaya.Rasa cemas akan memberikan respon pada tubuh untuk cepat melakukan perlindungan untuk memastikan keamanan. Reaksi emosi cemas ini positif dan baik apabila dirasakan dan direspon sewajarnya. Tetapi apabila direspon secara berlebihan atau reaktif akan menyebabkan suatu Gangguan Cemas (anxiety), yang ditandai dengan gejala-gejala: khawatir, gelisah, panic, takut mati, takut kehilangan control, jantung berdebar lebih kencang, nafas sesak, pendek, berat, perut mual, kembung, diare, kepala pusing, berat, terasa ringan, kulit terasa gatal, kesemutan, otot otot terasa tegang dan nyeri, gangguan tidur. Gangguan mental yang dialami individu akan berdampak psikologisna, yang membuat individu mengalamai gangguan emosi, dan dapat mempengaruhi kondisi fisik seperti merasa mudah lelah, jenuh, pusing, mual, dan gangguan pencernaan.

Kesehatan mental adalah terwujudnya keserasian yang sungguhsungguh antara fungsifungsi kejiwaan dan terciptanya penyesuaian diri antara manusia dengan dirinya sendiri dan lingkungannya. Tujuan kesehatan mental adalah mewujudkan manusia yang beradab, mampu menghadapi segala hambatan dalam hidupnya, Sehingga dapat berjalan menurut tujuan manusia itu diciptakan secara normal. Untuk itu di sini penulis akan memaparkan tentang apa itu kesehatan mental dan bagian-bagian lainnya.

Kesehatan mental menurut seorang ahli kesehatan Merriam Webster, merupakan suatu keadaan emosional dan psikologis yang baik, dimana individu dapat memanfaatkan kemampuan kognisi dan emosi berfungsi dalam komunitasnya, dan memenuhi kebutuhan hidupnya sehari-hari (Dewi dalam Zulkarnain dan Fatimah, 2019). Kondisi mental masing-masing individu tidak dapat disamakan. Hal inilah yang membuat topic kesehatan mental bersifat urgent untuk diteliti dan dibahas karena berhubungan dengan potensi individu itu sendiri, keluarga dan lingkungan, serta komunitas-komunitas yang ada. dan diharapkan kesehatan mental yang utuh dapat mengoptimalkan diri para pihak-pihak yang berkepentingan dalam rangka menjalankan perannya dalam kehidupannya sehari-hari.

Ada beberapa pengertian yang terkait dengan kesehatan mental, dan telah ditemukan ada tiga ciri pokok mental yang sehat, yaitu (a). Seseorang melakukan penyesuaian diri terhadap lingkungan atau melakukan usaha untuk menguasai, dan mengontrol lingkungannya, sehingga tidak pasif menerima begitu saja kondisi sosialnya. (b). Seseorang menunjukkan keutuhan kepribadiaannya - mempertahankan integrasi kepribadian yang stabil yang diperoleh sebagai akibat dari pengaturan yang aktif. (c). Seseorang mempersepsikan "dunia" dan dirinya dengan benar, independent dalam hal kebutuhan pribadi. Sedangkan Federasi Kesehatan Mental Dunia (World Federation for Mental Health) merumuskan pengertian kesehatan mental sebagai berikut. (1). Kesehatan mental sebagai kondisi yang memungkinkan adanya perkembangan yang optimal baik secara fisik, intelektual dan emosional, sepanjang hal itu sesuai dengan keadaan orang lain. (2). Sebuah masyarakat yang baik adalah masyarakat yang membolehkan perkembangan ini pada anggota masyarakatnya selain pada saat yang sama menjamin dirinya berkembang dan toleran terhadap masyarakat yang lain (Madani, 2013).

Dalam konteks Federasi Kesehatan Mental Dunia ini jelas bahwa kesehatan mental itu tidak cukup dalam pandangan individual belaka tetapi sekaligus mendapatkan dukungan dari masyarakatnya untuk berkembang secara optimal.

Kesehatan mental sama pentingnya dengan kesehatan fisik, keduanya memiliki keterlibatan satu sama lain, bilamana seseorang terganggu fisiknya maka ia dapat dimungkinkan terganngu mental atau psikisnya, begitupun hal sebaliknya. Sehat dan sakit merupakan kondisi biopsikososial yang menyatu dalam kehidupan manusia. Menurut Badan Kesehatan Dunia (WHO), Kesehatan mental merupakan kemampuan adaptasi seseorang dengan 
dirinya sendiri dan dengan alam sekitar secara umum, sehingga merasakan senang, bahagia, hidup dengan lapang, berperilaku sosial secara normal, serta mampu menghadapi dan menerima berbagai kenyataan hidup.

Terdapa dua hal besar yang mempengaruhi kesehatan mental yaitu faktor internal dan eksternal. Faktor internal ini antara lain meliputi: kepribadian, kondisi fisik, perkembangan dan kematangan, kondisi psikologis, keberagamaan, sikap menghadapi problema hidup, kebermaknaan hidup, dan keseimbangan dalam berpikir. Ada pun yang termasuk faktor eksternal antara lain: keadaan sosial, ekonomi, politik, adat kebiasaan dan sebagainya. Namun, yang paling dominan adalah faktor internal. Dijelaskan bahwa ketenangan hidup, ketenangan jiwa atau kebahagiaan batin itu tidak banyak tergantung pada faktor-faktor dari luar seperti keadaan sosial, ekonomi, politik, adat kebiasaan dan sebagainya. Akan tetapi lebih tergantung pada cara dan sikap menghadapi faktor tersebut. Pada program pengabdian masyarakat ini penulis akan melihat dari factor internal yaitu keseimbangan berpikir.

Saat kita berpikir dan merasakan emosi tertentu otak menghasilkan senyawa kimiawi yang disebut neuropeptida. Neuropeptida ini berfungsi sebagai pembawa pesan dan menyebar ke sel-sel di seluruh tubuh dan mencari reseptor atau docking station yang sesuai untuk dapat menyampaikan pesan kepada DNA dalam sel. Melalui gen-gen inilah akhirnya dimengerti bagaimana kita dapat memengaruhi kesehatan tubuh melalui kondisi pikiran dan tubuh guna meningkatkan kesehatan, ketahanan fisik, dan kesembuhan.Dari hasil penelitian ditemukan bahwa hampir $90 \%$ gen dipengaruhi oleh interaksi dengan keluarga, lingkungan, tempat kerja, teman, rekan kerja, stres, makanan, gaya hidup, praktik spiritual, kondisi emosi, dan lain-lain. Penyakit mental dapat menyebabkan masalah dalam kehidupan sehari-hari, tidak hanya dapat merusak interaksi atau hubungan dengan orang lain, namun juga dapat menurunkan prestasi di sekolah dan produktivitas kerja. oleh sebab itu, sudah saatnya kita menjalankan pola hidup sehat.

Di dalam penelitiannya Adi, Mangalik, dan Ranimpi (2020) dikatakan bahwa Gizi merupakan salah satu faktor pentingyang menentukan tingkat kesehatan dankeserasian antara perkembangan fisik dan mental. Selain itu penelitian Anggraini (2014), hubungan depresi dan gizi juga menemukan bahwa ada hubungan antara depresi dan gizi.

Gizi kurang dapat berdampak pada Sumber Daya Manusia yang buruk di masa mendatang, tidak rapi, ceroboh, sering lupa, gagal dalam memahami instruksi, anak nampak bodoh dan cenderung dihindari teman-temannya karena kurang dapat bekerja sama atau bersama dalam kelompok, hal demikian membuat anak tersisih dalam pergaulan (Santoso,2008). kurang gizi juga medapat menyebabkan menurunnya tingkat produktivitas otak, sehingga menyebabkan munculnya berbagai penyakit psikis, salah satunya yaitu depresi.Orangorang yang menderita depresi memiliki kecenderungan tidak memperhatikan pola makan dan aktivitas fisiknya berkurang sehingga mengakibatkan berat badan menjadi naik dan menjadi gemuk (Surilena \& Agus, 2006).

Hal tersebut dapat menimbulkan berbagai dampak antara lain menurunkan daya tahan tubuh sehingga mudah terkena penyakit (Soekirman, 2000). Gizi lebih (baik overweight maupun obesitas) juga tidak baik. Gizii lebih menyebabkan remaja menjadi malas, kurang aktivitas dan akan terbawa sampai usia dewasa dan lansia, keadaan gizi merupakan faktor risiko dari beberapa penyakit degeneratif dan metabolik.Dalam hal tertentu, stress, tugas beban kerja tinggi terjadi peningkatan asupan energi, lemak, karbohidrat dan protein, yang ditunjukkan dengan perbedaan rata-rata asupan energi (Chaput \& Tremblay, 2007). Asupan makan merupakan faktor yang berpengaruh langsung secara linier dalam menentukan status gizi seseorang. Konsumsi makan berpengaruh terhadap status gizi seseorang (Saniawan, 2009).Pada keadaan depresi, seseorang cenderung lupa akan pemenuhan kebutuhan dasar, seperti kebutuhan akan makanan, kebersihan diri dan istirahat. Apabila asupan makanan rendah dan berlangsung dalam jangka waktu yang relatif panjang, seseorang akan mengalami defisiensi zat gizi yang berakibat pada penurunan status gizi (Bonnie, 2000). Hal ini menimbulkan adanya dugaan bahwa gangguan kesehatan mental dapat juga diatasi secara mandiri dengan mengonsumsi makanan bergizi tinggi, cukup tidur, mengurangi asupan kafein, minuman beralkohol, atau zat penenang lainnya, tidak merokok, berola raga secara rutin, dan melakukan metode relaksasi sederhana, seperti yoga atau meditasi. (Promkes, 2018). Ada beragam hal yang dapat memicu terjadinya depresi, mulai dari peristiwa dalam hidup yang menimbulkan stres, kehilangan orang yang dicintai, merasa kesepian, hingga memiliki kepribadian yang rapuh terhadap depresi.

Permasalahan dan data yang telah diuaikan di atas mengarah kepada fakta bahwa menjaga kesehatan fisik dan mental telah menjadi suatu hal penting di masa pandemic ini. Sehingga perlu dilakukannya intervensi kepada masyarakat dengan memberikan pengetahuan mengenai pentingnya asupan gizi pada kesehatan mental dalam bentuk sosialisasi webinar. Diharapkan setelah mengikuti program ini diharapkan peserta lebih memahami 
pentingnya menjaga kesehatan mental dan asupan gizi sehari-hari dalam menunjang kesehatan fisik dan psikologis.

\section{Metode Pelaksanaan}

Program Pengabdian Masyarakat ini dilakukan dalam bentuk webinar dengan peserta masyarakat Indonesia yang di wakili oleh para bapak dan ibu rumah tangga yang bekerja, dan aktivis akademik di lingkungan Universitas Esa Unggul. Program ini dilakukan dengan menggunakan media daring dalam bentuk webinar yang berdurasi selama empat jam. Di akhir acara para peserta diberikan kuesioner yang mengukur pengetahuan tentang kesehatan mental dan kepuasan dari peserta seminar.

Instrument yang digunakan dalam program ini berupa kuesioner yang disusun untuk mengukur seberapa efektif program ini terhadap pembentukan pengetahuan peserta mengenai kesehatan mental dan asupan gizi. Instrumen yang lain adalah polling sebagai pendamping kuesioner pertama. Polling dilakukan untuk mengukur kepuasan para peserta dalam mengikuti Program Pengabdian Masyarakat.

\section{Hasil dan Pembahasan}

Berdasarkan hasil pengolahan data dengan menggunakan program statistic, diperoleh hasil polling, diketahui bahwa terdapat $49 \%$ menyatakan menarik, $41 \%$ peserta menyatakan bahwa program pengabdian masyarakat yang dilakukan sangat menarik, dan sisanya $14 \%$ cukup menarik. Kemudian peserta juga menyatakan bahwa Program Pengabdian Masyarakat disampaikan dengan baik sebesar 59\%, sangat baik 35\%, dan cukup baik 7\%. Ketercapaian dari tujuan Program Pengabdian Masyarakat yang menyatakan program tercapai sebesar 66\%, sangat tercapai 175, dan cukup tercapai $17 \%$. Kemudian dari seluruh peserta (100\%) mengatakan ingin mengikuti kembali program yang sama bila diadakan kembali. Data selanjutnya adalah peserta yang menilai penyampain materi dengan sangat baik berjumlah $62 \%$, yang menilai baik $28 \%$, dan yang menilai cukup baik berjumlah $10 \%$.

Bila dilihat dari sebaran hasil polling yang dilakukan, maka dapat disimpulkan bahwa Program Pengabdian Masyarakat yang telah dilakukan telah berhasil meningkatkan pengetahuan peserta dalam memahami pengtingnya menjaga kesehatan mental di masa pandemic ini. Hasil ini juga didukung dari perolehan nilai peserta dalam menjawab pertanyaan yang disajikan. Diketahui bahwa peserta yang menjawab pertanyaan nomer satu benar sejumlah $44 \%$, pertanyaan nomer 2 sejumlah $30 \%$ yang benar, peserta yang menjawab benar pertanyaan nomer tiga $84 \%$, peserta yang menjawab benar pertanyaan nomer empat $33 \%$, dan peserta yang menjawab benar pertanyaan nomer 5 sejumlah 64\%. Dan bila dibuat rata-rata terdapat $64 \%$ peserta yang mampu menjawab benar seluruh pertanyaan yang diberikan. Artinya bahwa Program Pengabdian Masyarakat yang diadakan efektif dalam meningkatkan pengetuan peserta dalam memahami pentingnya kesehatan masyarakat di masa pandemic pada khususnya dan kehidupan pada umumnya.

Pemahaman yang didasari oleh pengetahuan yang baik mengenai kesehatan mental pada peserta dapat meningkatkan perilaku peserta dalam menjaga kesehatan mentalnya. Peserta yang memiliki informasi yang baik tentang kesehatan mental mampu meningkatkan kualitas hidupnya di masa yang akan datang. Peserta tidak mudah terprovokasi, mampu berpikir tenang dan positif dan mampu melakukan pengambilan keputusan yang tepat. sehingga peserta tersebut akan lebih bahagia, menghargai segala kemampuan yang dimilikinya, termotivasi untuk mengembangkan gaya hidup yang lebih baik, dan mau bekerja keras serta tidak mudah putus asa di dalam menghadapi situasi kondisi dalam kehidupannya.

Berbeda dengan peserta yang kurang memiliki pengetahuan mengenai kesehatan mental, ia akan mudah merasa putus asa, tidak berdaya, rendah diri, merasa diri tidak berharga, selalu berpikir negative tentang dirinya dan memiliki kualitas hidup yang tidak sejahteran. Hal ini sejalan dengan hasil penelitian yang dilakukan oleh Wijayanti, Pohan, dan Nugroho (2017) mengenai hubungan persepsi pasien tentang penyakitnya dengan tingkat kecemasan, diperoleh hasil bahwa ada hubungan negative antara persepsi pasien tentang penyakitnya dengan tingkat kecemasan. Semakin positif persepsi pasien tentang penyakitnya maka akan menurunkan tingkat kecemasannya, sebaliknya semakin negative persepsi pasien tentang penyakitnya maka akan menaikkan tingkat kecemasan pasien tersebut. Sejalan pula dengan hasil penelitian yang dilakukan oleh Buana dan Hijrianti (2019) mengenai hubungan persepsi masyarakat terhadap pemerintah dengan kecemasan menghadapi rencana pembangunan jalur ganda kereta api, yang menghasilkan bahwa masyarakat yang memiliki persepsi positif terhadap pemerintah memiliki tingkat kecemasan yang rendah dalam menghadapi rencana pembangunan jalur ganda kereta api, sebaliknya masyarakat yang memiliki persepsi negative terhadap pemerintah memiliki tingkat kecemasan yang tinggi dalam menghadapi rencana pembangunan jalur ganda kereta api.

Berdasarkan hasil uji statistic yang telah dilakukan dan didukung oleh beberpa hasil penelitian sebelumnya, maka dapat disimpulkan bahwa pengetahuan yang dimiliki oleh peserta Program Pengabdian Masyarakat dapat membentuk pola berpikir yang baik atau persepsi pada 
masyarakat terhadap covid-19 dapat mempengaruhi kesehatan mental dari masyarakat tersebut.

\section{Kesimpulan}

Hasil dari Kegiatan Program Pengabdian Masyarakat yang dilakukan, dapat disimpulkan bahwa pemberian informasi dan pengetahuan mengenai kesehatan mental dapat mempengaruhi kemampuan peserta dalam menghadapi gangguan kesehatan mental. Peserta yang memahami materi yang disampaikan juga lebih banyak (64\%) dibandingkan peserta yang kurang memahami, dan $66 \%$ peseta menilai bahwa program yang dilakukan tercapai.

\section{Daftar Pustaka}

Adi, Mangalik, \& Ranimpi. (2020). Correlation between Dietary Habit and Nutritional Status with Mental Health Status of Elementary School Students. Jurnal Kesehatan. Vol 11 (1) . Hal. $93-100$. ISSN 2086-7751 (Print), ISSN 2548-5695 (Online)

Buana, C dan Hijriyanti, U.R. (2019) Hubungan Persepsi Masyarakat Terhadap Pemerintah Dengan Kecemasan Menghadapi Rencana Pembangunan Jalur Ganda Kereta Api. Jurnal Proyeksi. Vo. 14(2). Hal. 94-114. EISSN 2656-4173

Daradjat, Z. 2001. Kesehatan Mental. Jakarta: PT Toko Gunung Agung

DI, A. (2014). Hubungan Depresi dengan Status Gizi. Medula Unila, Vol. 2(2), 39--46.

Dianapuspitasari (2020). Pengaruh Gizi terhadap Perkembangan dan Kesehatan Mental pada Remaja. www.kompasiana

Fassah dan Retnowati (2014). Hubungan Antara Emotional Distress Dengan Perilaku Makan Tidak Sehat Pada Mahasiswa Baru. Jurnal Psikologi. Vol. 10 (1). Hal. 11 - 17

Kementrian Kesehatan Mental. (2018). https://promkes.kemkes.go.id/pengertiankesehatan-mental

Kesehatan Mental: Pengertian, Faktor yang Mempengaruhi dan Paradigma. http://www.indopositive.org/2019/10/keseha tan-mental-pengertian-faktor-yang.html

http://madanionline.org/definisi-kesehatan-mental/
Putri, A. W., Wibhawa, B., \& Gutama, A. S. (2015). Kesehatan mental masyarakat Indonesia (pengetahuan, dan keterbukaan masyarakat terhadap gangguan kesehatan mental). Prosiding Penelitian dan Pengabdian kepada Masyarakat, 2(2).

Sabarini. https://dosenpsikologi.com/pengaruh-giziterhadap-perkembanganmental\#: :text=Jiwa\% 20Menjadi\%20Lebih $\% 20$ Semangat,dalam\%20menyerap $\% 20 \mathrm{hal}$ \%20yang\%20positif

Wijayanti, W., Pohan, V.F., Nugroho. (2017). Hubungan Persepsi Pasien Tentang Penyakitnya Dengan Tingkat Kecemasan Di Polikilinik Rawat Jalan Rumah Sakit Roemani Muhammadiyah Semarang. Skripsi.

http://repository.unimus.ac.id/2015/2/MAN USCRIPT.pdf. Diakses tanggal 20 November 2020.

Zulkarnain dan Fatimah. (2019). Kesehatan Mental dan Kebahagiaan. Mawa'izh: Jurnal Dakwah dan Pengembangan Sosial Kemanusiaan. Vol. 10, no. 1 (2019), pp. 1838.DOI:https://doi.org/10.32923/maw.v10i1. 715 